\title{
Comparative studies on flexibility characteristics of steel and fanpalm reinforced two bay concrete portal frames
}

\author{
${ }^{1}$ Raheem A. A. and ${ }^{2 *}$ Audu M. T. \\ ${ }^{1}$ Department of Civil Engineering, Ladoke Akintola University of Technology Ogbomoso, Nigeria \\ ${ }^{2}$ Department of Civil Engineering, University of Abuja, FCT, Abuja, Nigeria \\ *Corresponding Author E mail: tosagigal2000@yahoo.com
}

\begin{abstract}
Reinforced concrete constitutes over $90 \%$ of the infrastructures in developing countries and over $75 \%$ of constructed facilities in industrialized nations. Steel is the main material used as reinforcements in the structural members. Steel is expensive and the need to find alternative locally available, suitable material to steel is a quest to researchers. The use of Fanpalm, as a locally available material as reinforcement in place of steel in portal frames is the main focus of this study. The theoretical and experimental investigation of the flexural strengths, deflection characteristics and cracking behaviors of fanpalm/steel reinforced two bay concrete portal frames were examined. The result showed linear load-deflection curves up to the first crack, thereafter, a non linear relationship between the load and deflection occurred irrespective of the reinforcement used. The fanpalm reinforced portal frames exhibited larger deflections, increased crack numbers and crack widths compared with equivalent steel reinforced ones. The numbers of cracks formed and the load carrying capacities (flexural strength) of the frames up to failure point increased with increase in percentage of reinforcements.
\end{abstract}

Key words: concrete; fanpalm, flexibility, portal frame; steel.

\section{Introduction}

Concrete is the most widely used construction material globally (Ishaya et al., 2016). This was attributed to its versatility, strength, durability and ease of placement. Also, steel is the commonest reinforcements often used in concrete. Cement and Steel is expensive and often led to the cost of buildings and other structures out of reach for common men. Various researchers have investigated the utilization of alternate materials to conventional steel reinforced building materials in terms of aggregates, cement and reinforcements. For aggregates; palm kernel shells (Olugbenga et al., 2015 and Oti et al., 2015), coconut shells (Abdullahi et al., 2017) expanded polystyrene beads, recycled aggregates (Veena et al., 2016), Waste bottle caps (Ishaya et al., 2016) and the ashes from the cocoa nut and palm kernel were investigated. They all reported that these materials could be used as a partial replacement for coarse and fine aggregates in concrete production at a percentage not more than $25 \%$ of normal aggregate. Also, alternative cementing materials investigated by various researchers are: ashes of various agricultural wastes; ricehusk, cornshealths, burnt clay, lime and fly ash (Raheem, 2006; Sera et al., 1990; Shimzu and Jorillo, 1992; and Yinusa and Danladi, 2013). The researchers recommended partial replacements of cement with the ashes from within a range of 10 to $15 \%$ replacement. In the case of reinforcements, the use of fibres to improve strength and ductility of the brittle materials has been adopted with the use of straw, horse-hair in bricks and other mortal products (Shimuzu and jorillo, 1992, Marikunte and Soroushian, 1994 and, Pama et al., 1976). The use of natural vegetable fibres as a composite material has also gained interest in the last decade. The distinctive properties of this composite concrete (natural fibre reinforced concrete) are: improved tensile and bending strength, greater ductility, greater resistance to cracking, improved impact strength and toughness (Azis et al., 1984, Ramakrishna and Sunderrajan, 2005 and Toledo et al., 2000).

Other local reinforcing materials to steel studied are: bamboo, Akwara natural vegetable fibre, Pankere, Datepalm mid ribs, but these materials were found to deteriorate with time, dimensionally unstable, 
susceptible to termite attack and decaying in alkaline and water environments (Al-Oraimi and Seibi, 1995, Nelson and Marshal, 2003, and Youssef, 1976). It was concluded that these materials are not suitable substitute to steel because of durability problems. Then the need to investigate other locally available material became imperative. One of such material is fanpalm. Fanpalm is a local material that belongs to palmea plant group Ushe and Oclo, (1979). It is a tree very common in tropical countries like Asia and Africa. The tree trunk is usually 30 to $40 \mathrm{~cm}$ in diameter, usually straight and 10 to $15 \mathrm{~m}$ tall when fully matured, Ibi, (1988). Researchers; Audu (1989), Ibi (1988), Jimoh (2006), Shimizu and Jorillo (1992) have found out that after air dried, fanpalm is dimensionally stable, resistant to termite attack and does not decay easily like bamboo. These researchers reported that the mechanical strength varies within 130 - 150 $\mathrm{N} / \mathrm{mm}^{2}$ in tension and $70-80 \mathrm{~N} / \mathrm{mm}^{2}$ in compression. The use of fanpalm as reinforcing materials in concrete elements has been ongoing studies in the past decades. It was reported that fanpalm reinforced beams and slabs behave similar to steel reinforced concrete beams and slabs but fanpalm reinforced members deflect more than equivalent steel reinforced members and also has lesser load carrying capacities (Audu, 1989 and Jimoh, 2006). In the recent research paper by Audu and Raheem (2017) on flexural behavior of fanpalm reinforced slabs, it was reported that experimental first crack and yield loads were higher compared with theoretical loads for fanpalm reinforced slabs. Also, the cracks in fanpalm reinforced slabs were more than the equivalent steel reinforced slabs. This paper studied the flexural behaviors of two bays portal frames reinforced with fanpalm and steel subjected to uniformly distributed loads (UDL). The need to study portal frames reinforced with natural fibers is also very important because portal fames structures are very common and has wide applications and steel has been the reinforcements commonly used.

Portal frame are generally low rise structures comprising vertical column and horizontal or pitched rates connected by moment resisting connections (Nasiru, 1995 and https, Wikipedia). It is usually constructed using steel or steel reinforced precast concrete or timber (www.steel construction). Portal frame members are fixed or rigidly connected and hence transmit axial and normal loads, also transmit moment at the joints. Hence move stable compared to trusses. A portal frame building comprises a series of transverse frames that are braced longitudinally (https.wikipedia and www.steel consruction). Reinforced concrete portal frame is a structural system that comprise of concrete and reinforcements. Steel is commonly used as reinforcement but the use of natural fibers as reinforcement is a possibility and it is the focus of this study. The primary function of the reinforcements in concrete structural elements is to take up tensile stresses which concrete cannot take (Mosley and Bungey, 2000). In this paper, the Flexural behaviors of two bay portal frames reinforced differently with fanpalm and steel and subjected to same loading conditions is presented. The Properties of fanpalm that have motivated its selection for this study are: availability, high strength and resistance to termite, rot and decay (Usher and Oclo, 1979). It was also reported that fanpalm is of higher durability than other vegetable fibres and its durability could be improved when coated with blocking and repelling agents (Audu and Raheem, 2017).

\section{Methodology}

Fanpalm reinforcements were prepared by slicing and smoothing at the faces into rectangular shapes of size $10 \mathrm{~mm}$ x $10 \mathrm{~mm}$ (cross-sectional) and of lengths $1460 \mathrm{~mm}$ and $510 \mathrm{~mm}$. These fanpalm were arranged as reinforcements in the beams and columns of the portal frames as shown in Fig1. Steel reinforcements of $8 \mathrm{~mm}$ diameter were arranged exactly like the arrangement of fanpalm reinforcements discussed above. Wooden moulds of $1500 \mathrm{~mm}$ long, 100 wide and $(100$ and $120 \mathrm{~mm})$ deep were prepared for beams' formwork. While, wooden moulds of $550 \mathrm{~mm}$ long, $100 \mathrm{~mm}$ wide and depths of $90 \mathrm{~mm}$ and $95 \mathrm{~mm}$ columns' formwork were also prepared. The variation in depths of the beams and columns is to produce a varying cross sectioned two bay steel/fanpalm reinforced and unreinforced concrete that is subjected to a uniformly distributed loading, UDL, for the study as shown in Fig1. While Fig 2 is a sample of produced two bay portal frame reinforced with fanpalm. 
LAUTECH Journal of Civil and Environmental Studies

Volume 2, Issue 1; 2019
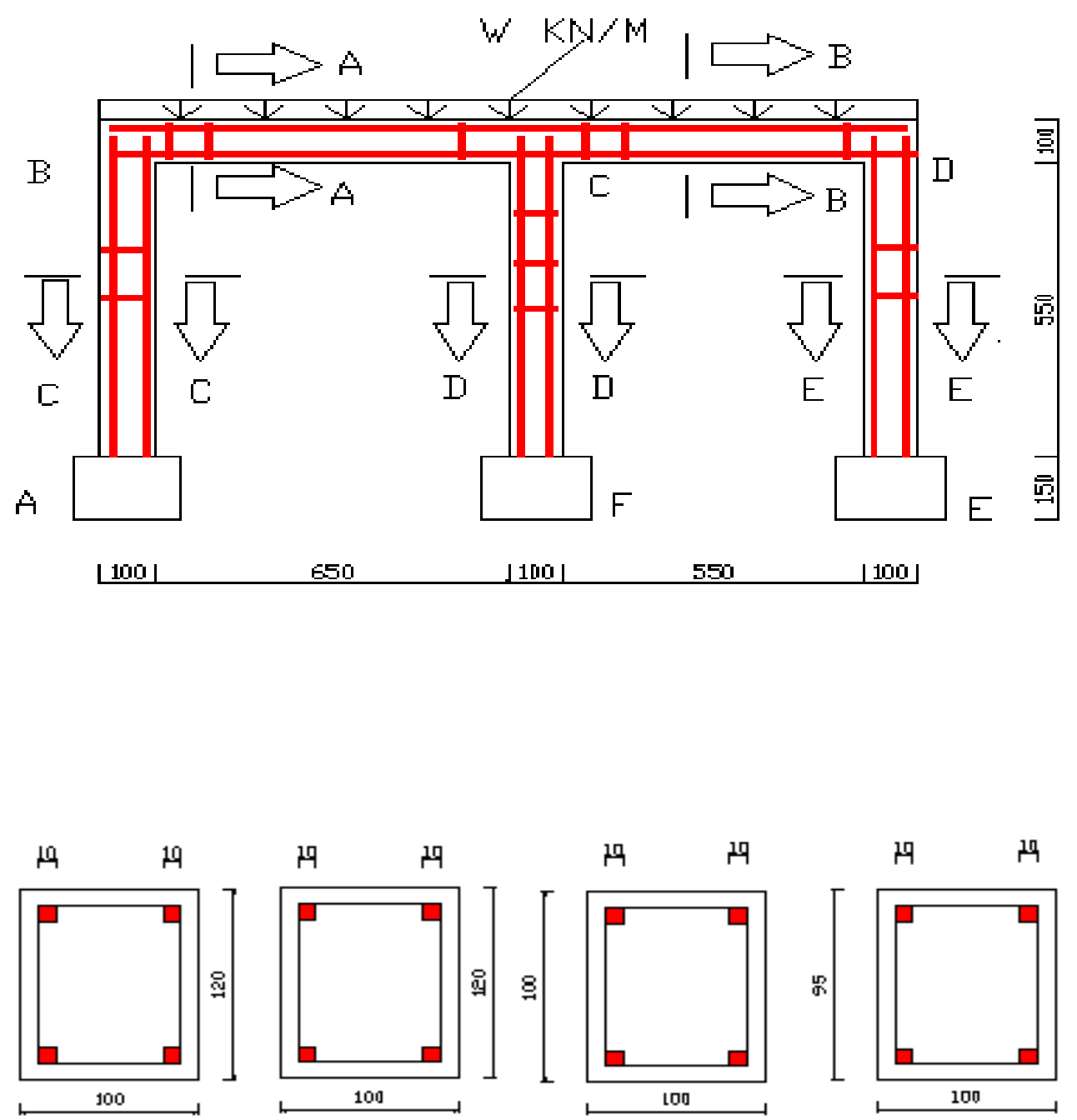

Section $A-A$

Section $B-B$

Section $C-C$ \& $E-E$

Section $D-D$

Reinforcement (fanpalm/steel) 

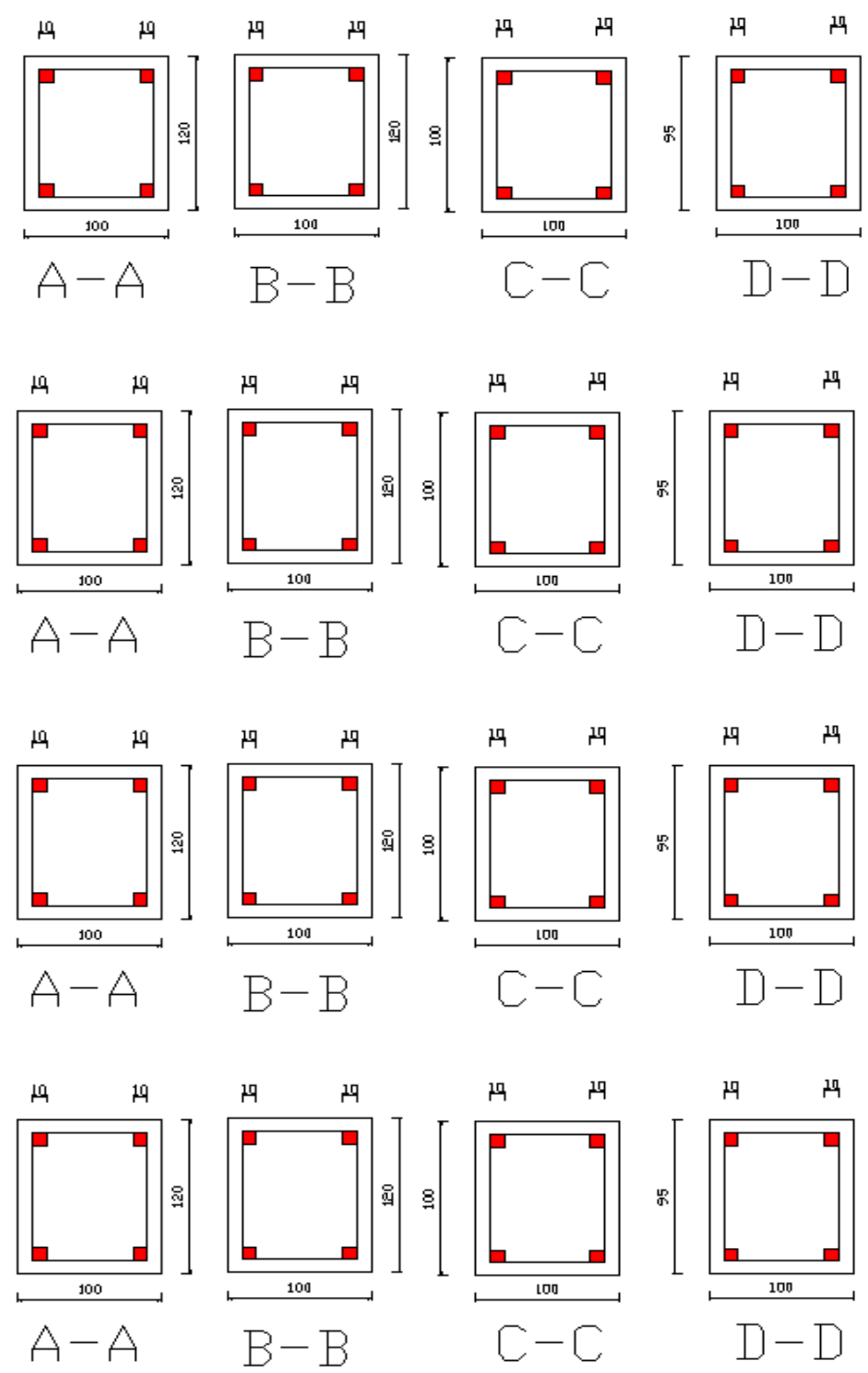

All dimensions are in mm, $8 \mathrm{~mm}$ stirrups at 200mm C/C for both the beams and columns, $8 \times 10 \mathrm{~mm}$ fanpalm reinforcements

Fig. 1: Theoretical two-bay fanpalm reinforced portal frame 


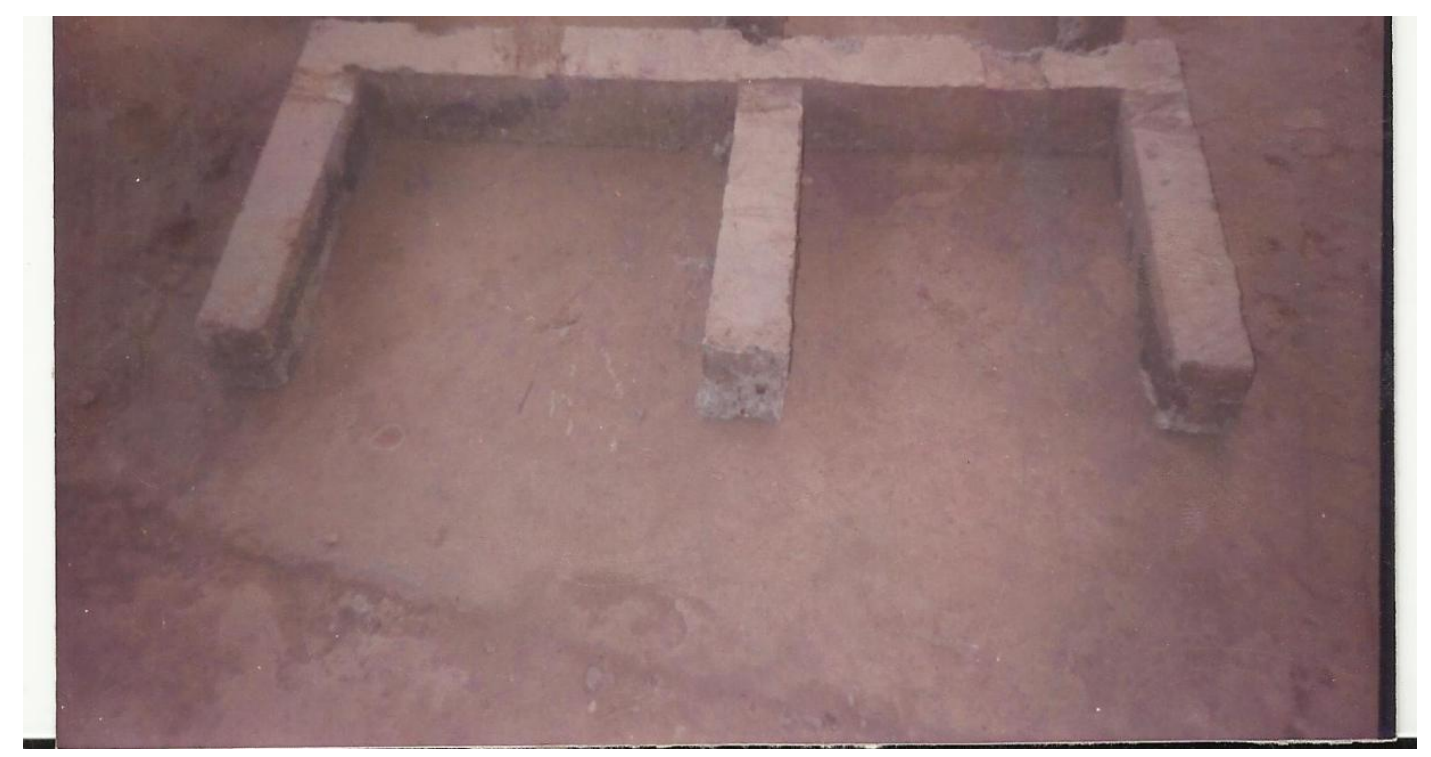

Fig 2: Experimental two bay concrete portal frame (specimen 1)

The reinforced concrete portal frames were produced by placing the wooden moulds on a paper spread on the leveled floor. Then the internal surfaces of the moulds oiled to prevent adhesion of concrete onto the surfaces. Concrete layer of $20 \mathrm{~mm}$ of 1:2:4 mix then poured into the moulds which served as cover for the reinforcements. The portal frame reinforcements were placed in the moulds on the concrete cover and more concrete poured until the moulds were full. The fresh concrete in the mould was tamped gently with $25 \mathrm{~mm}$ square steel tamping rod. A trowel was used to give a smooth surface and to trim off excess concrete that protruded out of the moulds. They were cured in water under the laboratory conditions for 28 days before subjected to flexural strength and deflection tests. The two bay portal frames were positioned and steel channels of flat bases were placed on the frames so as to obtain a UDL loading on the two bay portal fames and dialguages were mounted at the middle of the bays, see Fig 2. These arranged system was placed under the frames of the universal testing machine. The universal testing machine was the set at the loading rate of $1 \mathrm{kN} / \mathrm{min}$. The load then applied gradually by the machine on the beams of the portal frame structure via a special fabricated steel block mounted on the beam of the frame to induced uniformly distributed load on the beams of the portal frame. The corresponding dialgauge readings were recorded. The loading continued until the frame ruptured, the dialguage readings were recorded to measure the deflections and the corresponding failure loads from the scale of the Universal testing machine.

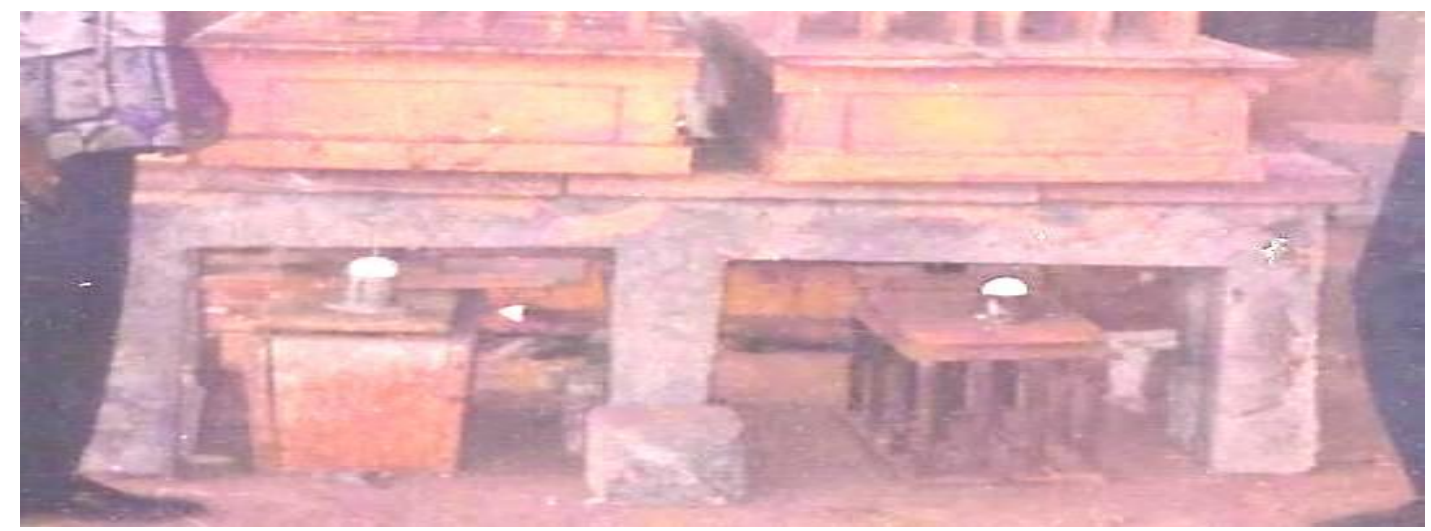

Fig 3: Experimental Set up of deflections of two bay portal frames (specimen 1) 


\section{Results and Discussion}

Table 1 presents the dimensions, properties as well as the theoretical and experimental failure loads of the various types of the tested two bay portal frames. The deflection - load curves for the tested two bay portal frames for the frames reinforced with;

- Reinforced with $1.30 \%$ fan palm reinforcements (Specimen 1)

- Reinforced with $1.60 \%$ fan palm reinforcements (Specimen 2)

- Un-Reinforced (Specimen 3)

- Reinforced with $8 \mathrm{~mm}$ diameter high yield steel reinforcements (Specimen 4) are presented graphically in Fig 3, 4, 5 and 6 respectively.

It was observed that the gradient of the curves are relatively large until the first crack appears at the bottom of the beams of all the tested Two Bay Portal Frames. At loads below the first cracks, all curves irrespective of the type and the percentage reinforcements followed the same pattern, indicating that fanpalm plays no role in controlling the first crack. Immediately after the first crack appear the load deflection curves gradient continued to be less steep as the cracks widened and multiplies until failure occurred.

Table 1: The properties and failure loads of the two bay portal frames

\begin{tabular}{|c|c|c|c|c|c|c|}
\hline \multirow{2}{*}{$\begin{array}{ll}\text { Member } & \\
& \\
\text { BC } & 1 \\
& 2 \\
& 3 \\
\end{array}$} & \multirow{2}{*}{$\begin{array}{l}\text { Type of } \\
\text { Reinforcement } \\
\text { Fanpalm }\end{array}$} & \multirow{2}{*}{$\begin{array}{l}\% \text { of } \\
\text { Reinforcement } \\
1.33\end{array}$} & \multirow{2}{*}{$\begin{array}{l}\mathrm{H}(\mathrm{mm}) \\
120\end{array}$} & \multirow{2}{*}{\begin{tabular}{|l}
$\begin{array}{l}\mathrm{D} \\
(\mathrm{mm})\end{array}$ \\
95 \\
\end{tabular}} & \multicolumn{2}{|c|}{$\begin{array}{l}\text { Failure load }(\mathrm{kN}) \\
\text { Theoretical } \\
\text { Experimental }\end{array}$} \\
\hline & & & & & $\begin{array}{l}4.70 \\
4.70 \\
4.70 \\
\end{array}$ & $\begin{array}{l}4.88 \\
4.85 \\
4.75 \\
\end{array}$ \\
\hline Average & & 1.33 & 120 & 95 & 4.70 & 4.80 \\
\hline $\begin{array}{ll}\mathrm{CD} & 1 \\
& 2 \\
& 3\end{array}$ & Fanpalm & 1.60 & 100 & 75 & $\begin{array}{l}2.53 \\
2.53 \\
2.53\end{array}$ & $\begin{array}{l}2.65 \\
2.70 \\
* 3.50\end{array}$ \\
\hline Average & & 1.60 & 100 & 75 & 2.53 & 2.68 \\
\hline $\begin{array}{ll}\mathrm{BC} & 1 \\
& 2 \\
& 3\end{array}$ & unreinforced & 0.00 & 120 & 95 & $\begin{array}{l}0.45 \\
0.45 \\
0.45\end{array}$ & $\begin{array}{l}0.50 \\
0.60 \\
0.55\end{array}$ \\
\hline Average & & 0.00 & 120 & 95 & 0.45 & 0.55 \\
\hline $\begin{array}{ll}\text { CD } & 1 \\
& 2 \\
& 3 \\
\end{array}$ & unreinforced & 0.00 & 100 & 75 & $\begin{array}{l}0.20 \\
0.20 \\
0.20\end{array}$ & $\begin{array}{l}0.25 \\
0.22 \\
* 0.12\end{array}$ \\
\hline Average & & 0.00 & 100 & 75 & 0.20 & 0.24 \\
\hline $\begin{array}{ll}\mathrm{BC} & 1 \\
& 2 \\
& 3\end{array}$ & $\begin{array}{l}8 \mathrm{~mm} \text { high } \\
\text { yield steel }\end{array}$ & 0.47 & 120 & 95 & $\begin{array}{l}6.18 \\
6.18 \\
6.18\end{array}$ & $\begin{array}{l}6.20 \\
6.50 \\
6.50\end{array}$ \\
\hline Average & & 0.47 & 120 & 95 & 6.18 & 6.40 \\
\hline $\begin{array}{ll}\text { CD } & 1 \\
& 2 \\
& 3\end{array}$ & $\begin{array}{l}8 \mathrm{~mm} \text { high } \\
\text { yield steel }\end{array}$ & 0.57 & 100 & 75 & $\begin{array}{l}4.64 \\
4.64 \\
4.64\end{array}$ & $\begin{array}{l}4.70 \\
4.68 \\
4.66\end{array}$ \\
\hline Average & & 0.57 & 100 & 75 & 4.64 & 4.68 \\
\hline
\end{tabular}

$\mathrm{H}$ represent the overall depth, D represent effective depth, * values not used in average computations. 
LAUTECH Journal of Civil and Environmental Studies

Volume 2, Issue 1; 2019

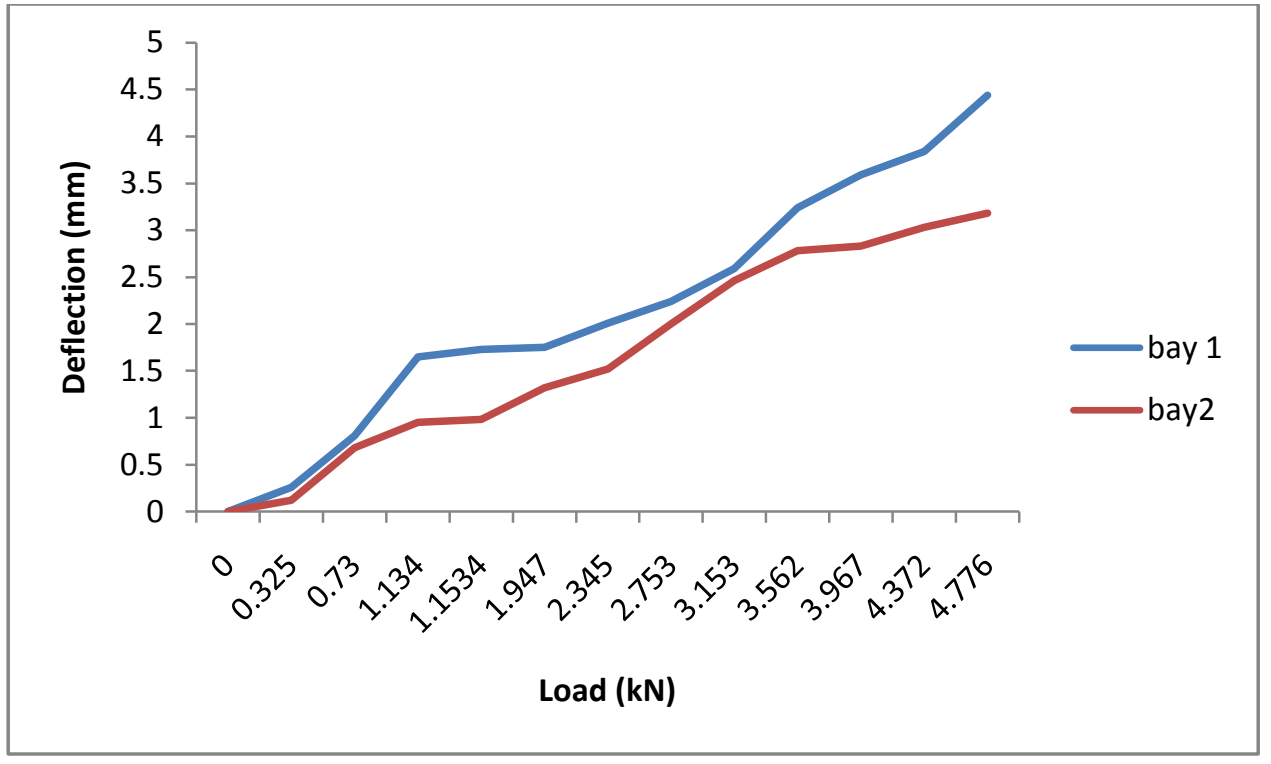

Fig 4: Deflection - Load curves for fanpalm reinforced portal frames (specimen 1)

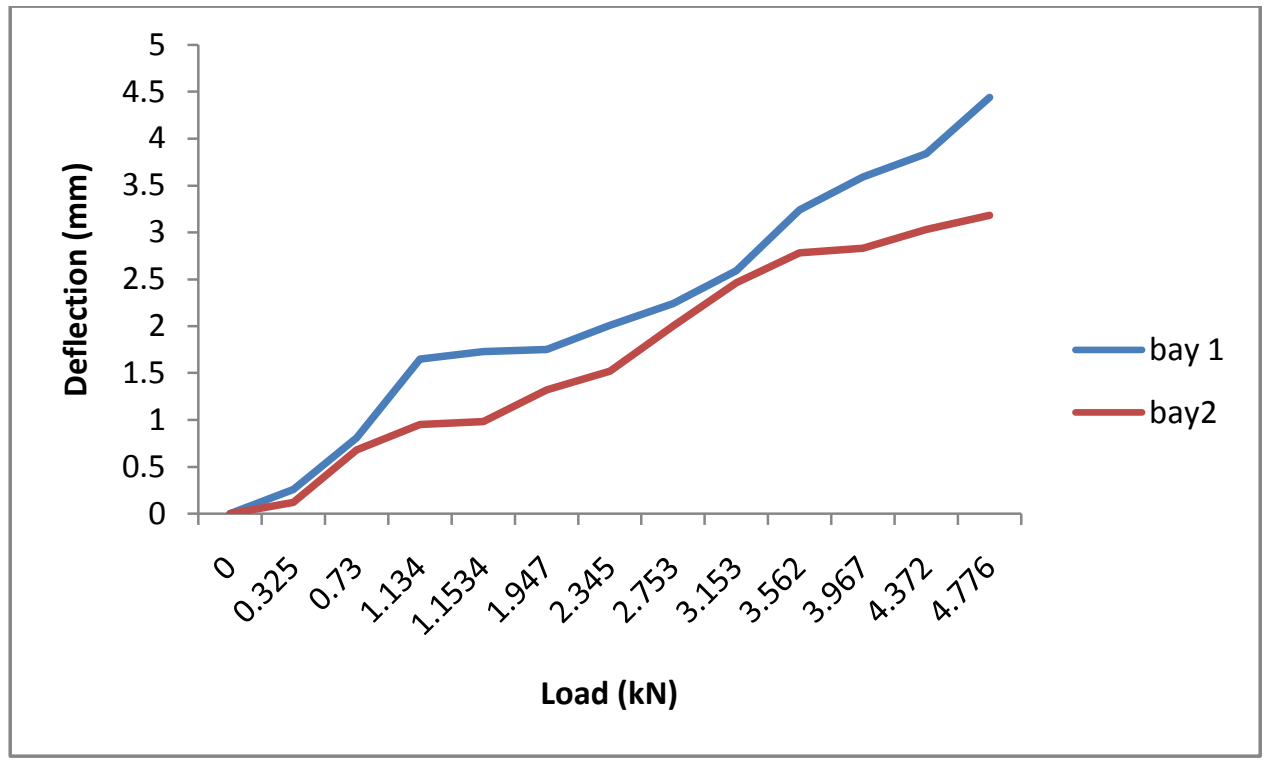

Fig 5: Deflection - Load curves for fanpalm reinforced portal frames (specimen 2) 


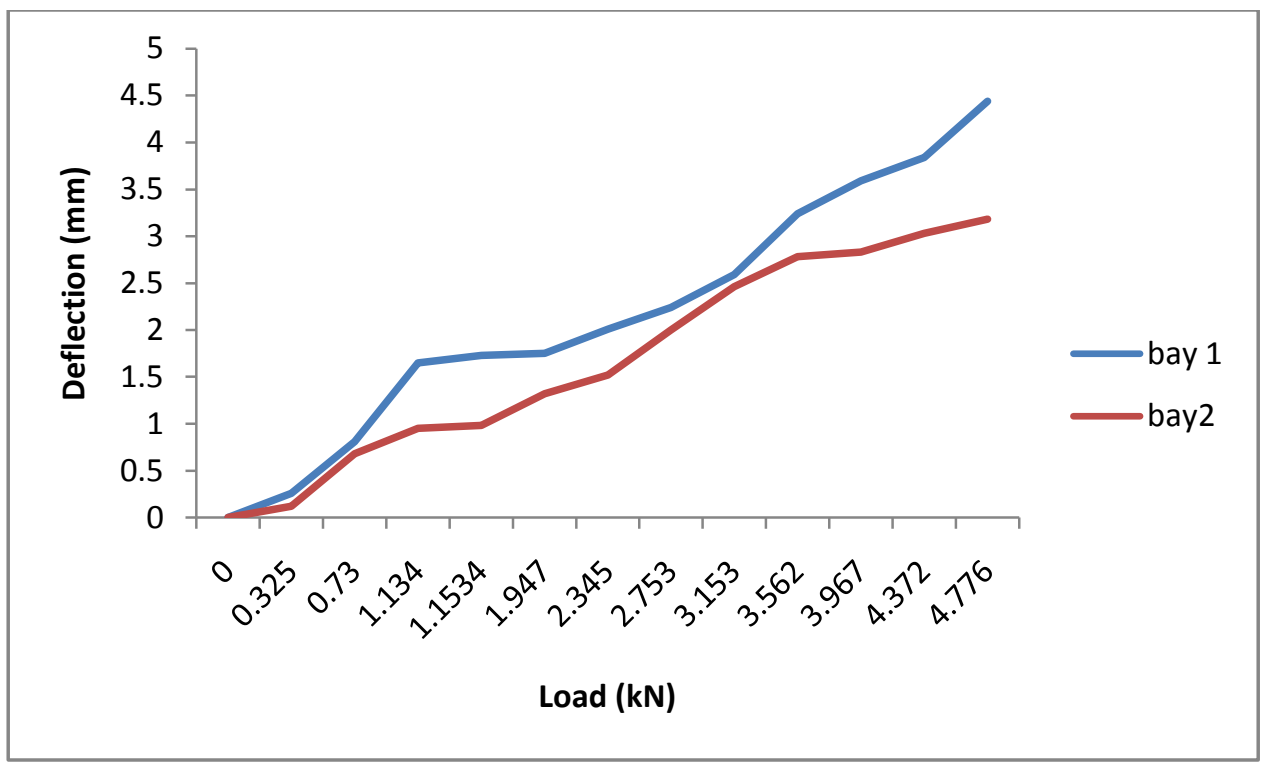

Fig 6: Deflection - Load curves for unreinforced portal frames (specimen 3)

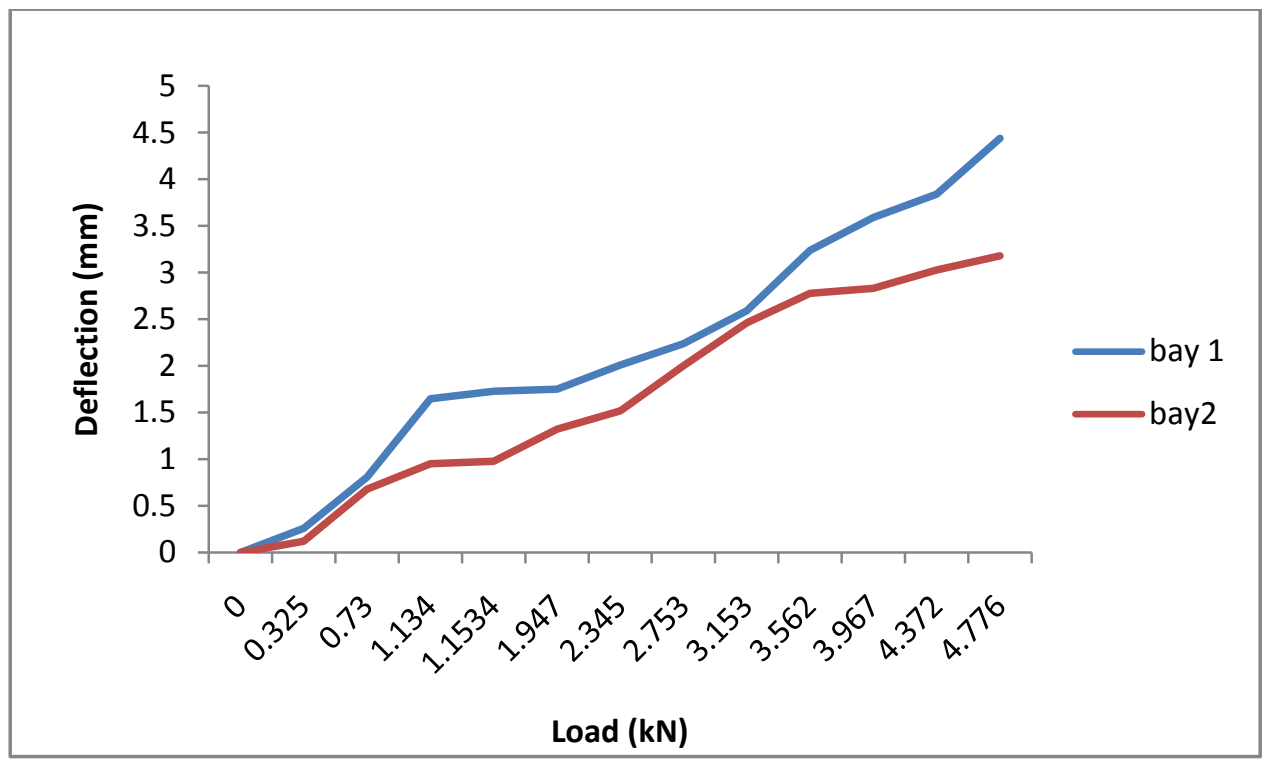

Fig 7: Deflection - Load curves for steel reinforced portal frames (specimen 4).

The result shown in Table 1 showed that the experimental failure loads are higher compared to theoretical failure loads for the fanpalm reinforced Portal Frames. The columns of plain two bay portal frame failed by buckling which gives no warning of failure while the fanpalm reinforced two bay portal frame of the same cross-section does not fail by buckling. There was no sign of any crack at the failure loads of unreinforced ones but the reinforced (fanpalm and steel) failed at a much higher loads with prop sound and large deflections before failure. This showed that fanpalm in two bay portal frames plays some role in improving the crack resistance and flexural strengths (tensile and compressive) in the columns and beams of the portal frames. The steel reinforced frames sustained higher loads with lesser deflections compared with equivalent fanpalm reinforced frames (Table 1, Fig 4, 5 and 7). 
It was observed that steel improved the crack resistance as the loads at crack for steel reinforced frames are higher than the loads at cracks for the equivalents fanpalm reinforced frames. However the first crack loads were almost same for all the frames (reinforced and unreinforced). This showed that reinforcement will not play significant role until the section has cracked. This is in compliance with the theory of reinforced sections (Yinusa and Danladi, 2013, Marikunte and Soroushian, 1994). It was observed in the course of the experiment that steel reduces the first crack widths in beams of portal frames more than the equivalent fanpalm reinforcement of the same dimension.

As the load applied to two bay portal frames was increased, the deflection also increased. The deflection increased sharply during the period of crack formation. These crack formation stopped when the two bay portal frames yielded. Further application of load to already cracked two bay portal frame at after this first yielding point increases the deflection more rapidly than before the crack and also increase the number of cracks formed. However, the number of cracks formed up to failure point of a two bay portal frame increased with increase in fanpalm percentage; for example beam with $1.33 \%$ fanpalm had one major crack at bottom at rapture, while beam with $1.60 \%$ fanpalm had two crack at the bottom.

All beam reinforced with $1.33 \%$ and $1.60 \%$ fanpalm failed by tension only and one of the beam with $1.6 \%$ fanpalm failed with crushing of concrete in compression zone, occurring simultaneously with rupture of fanpalm reinforcement in tension zone (balance failure). The mode of failure of steel reinforcement concrete two bay portal frames did not involve sharp increase in deflection during a crack formation. This could be due to higher steel modulus of elasticity when compared to fanpalm. The plain concrete (unreinforced) two bay portal frames broke completely into two in a brittle manner just after the first crack was formed.

It was observed that all the curves are linear up to first crack, implying that the two bay portal frames obey hooks' law until the appearance of the first crack; also, all the two bay portal frames have almost equal first crack load. The curves after the first crack do not show any definition curve shape. It was observed from Fig 3 and 4 that the higher the percentage of fanpalm reinforcements the higher the load carrying capacities of two bay portal frames.

Flexural cracking appears in the beams of two bay portal frame subjected to bending stress at any given point the stress exceeds the maximum ultimate stress. Précised measurement showed that stress which occur in a test specimen of this kind remain substantially proportional to the flexural stresses almost up to failure loads. There is slight deviation from proportionality that occurs just practically in the elastic range without any plastic hinge formation of the concrete. The origin of the cracks was attributed to; shrinkage of the concrete, temperature variation and the applied force.

\section{Conclusion}

(a) Fanpalm reinforced concrete portal frames require five times as much the area of the steel reinforcements used for steel reinforced concrete portal frames (Audu, 1989 and Usher and Oclo, 1979).

(b) The load carrying capacity of a fanpalm reinforced portal frame increased with increase in fanpalm reinforcement; however, the increase in not linearly related to the load increment (Fig 4 and 5).

(c) The fanpalm reinforced two bay concrete portal frames exhibited large deflections and increased crack widths, before final failure which could be attributed to low value of modulus of elasticity of fanpalm (Ramakrishna and Sunderrarajan, 2005).

(d) The comparison of the defection - load curves of fanpalm reinforced sections and unreinforced sections (Fig 4, 5 and 6) showed that fanpalm reinforcements do not contribute to the stiffness of the concrete sections.

(e) The experimental failure loads were greater than the theoretical failure loads. 


\subsection{Recommendations}

a) Fanpalm is very cheap and readily available in the developing, tropical zones countries, therefore the Federal Government in collaboration with Engineers should provide ways of using the fanpalm as a reinforcing element in low cost houses and frame structures that will sustains light to medium life loads.

b) According to this study, fanpalm should be used as reinforcements in frame structures to resist light to medium loads load because fanpalm has a low characteristic strength (i.e from 59.2 to $151.9 \mathrm{~N} / \mathrm{mm}^{2}$ ) which is just about $60 \%$ of the mild steel yield strength

c) Further investigations are needed in:

i) Creep determination of fanpalm reinforced two bay portal frame

ii) Durability studies of fan palm in concrete and other adverse environment.

\section{Acknowledgement}

The assistance of the staffs and management of Department of Civil and Mechanical Engineering of University of Abuja, University of Ilorin and Kwara State Polytechnics is deeply appreciated for providing the enable environments for this study. The support and technical assistance of the technologists in the strength of material laboratories of the above institutions during the course of preparation, and testing of the specimens is also acknowledged.

\section{References}

Abdullahi, M, Aminulai, H.O, Alhaji, B. and Abubakar. (2017). Modelling the slump, compressive strength and density of concrete containing coconut shells as partial replacement for crushed granite, Journal of Research Information in Civil Engineering, 14(1): 75 - 95

Al-Oraimi, S.K and Seibi, A.C. (1995).Composite Structure, ACI Materials Journal, 32(1): 165

Audu, M.T. (1989). Fan palm Reinforced Concrete Slab Subjected to Short Term Loading, unpublished B.Eng. Project Report, submitted to the Department of Civil Engineering, University of Ilorin, Nigeria. Audu, M.T. and Raheem, A.A. (2017). Fexural behavior of fanpalm reinforced concrete slabs, Journal of Building Engineering, 13: 63-67 (www.elsevier.com/locate/jobe)

Aziz, M.A., Paramasivam, P. and Lee, S.L. (1984). Concrete reinforced with natural fibres, New Reinforced Concretes (ed.) r n swamy (surrey: surrey University Press), pp. 106- 140.

Ibi, T.M.(1988) "The Behavior of Fan palm Reinforcement Concrete Beams and Slabs Subjected to Short-term Loading”, Unpublished B. Eng Project Report, submitted to the Department of Civil Engineering, University of Ilorin, Nigeria.

https://en.m.wikipedia.org. Portal Frame Construction

Ishaya, A., Oyemogun, I.M, Arinze, A.and Abah, J.C.(2016). Properties of concrete produced with waste bottle caps as partial replacement of coarse aggregate and orange leaves powder as plasticizer, Journal of Civil Engineering and Environmental Research, 8(7): 22 - 44.

Jimoh, A.A. (2006). Conversion and properties of fan palm (borassus aethiopum) for structural uses, unpublished Ph.D Thesis submitted to the Department of Civil Engineering, University of Ilorin, Nigeria.

Marikunte, S. and Soroushian, P. (1994). Statistical evaluation of long-term durability characteristics of cellulose fibre reinforced cement-composites. ACI Materials Journal, 91(6): 607-616

Mosley, W.H. and Bungey, R.H. (2000) Reinforced Concrete Design, Fifth edition, Macmillan Publishers Ltd, USA.

Nasiru, A. (1995). "The Flexural behavior of fan palm reinforced two-bay portal frame of varying cross section subjected to short term loading”, Unpublished final year project submitted to Department of Civil Engineering, Kwara State Polytechnics, Ilorin, Nigeria.

Nelson and Marshal, (1983). The Stuctures. Third edition, Published by Macmillan Publishers Ltd, USA. 
Olugbenga, J.O, Lekan, M.O, and Ebenezer, O.O. (2015). Investigation of palmkernel shell as partial replacement for aggregates in asphatic concrete, Malaysian Journal of Civil Engineering, 22(2):45 -62.

Oti, J.E, Kinuthia,J.M, Robinson, R. and Davis,P. (2015). The use of palmkernel shell and ash for concrete production. International Journal of Civil, Environmenta, Structural, Construction and Architectural Engineering, 9 (3): 78 - 91.

Pama, R.P., Cook , D.J., and Oranratnachi, A. (1976). Fibre mechanical and physical Properties of coir fibre boards, In Proceedings on New Horizons in Construction Materials. pp. 391-404.

Raheem, A.A. (2006). An Investigation of corn cob ash blended cement for concrete production. Unpublished Ph.D. Thesis, submitted to the Department of Building, Faculty of Environmental Design and Management, Obafemi Awolowo University, Ile - Ife, Nigeria.

Ramakrishna, G. and Sunderrarajan, T. (2005). Impact strength of a few natural fibre reinforced cement mortar slabs, A Comparative Study of Cement and Concrete Composites, 27(5): 547-553.

Sera, E.E., Roble, A.L. and Pama, R.P. (1990). Natural fibres as reinforcement, Journal of Ferrocement, 20( 2): 109-122.

Shimizu, G. and Jorillo Jr. P. (1992). Coir fibre reinforced cement based composite, Part1: Micro Structure and Properties of Fibre - Mortar. Proceeding of 4th International Symposium of RILEM Fibre Reinforced Cement and Concrete, Sheffield, U.K. Swamy, R.N. (Ed.), E and FN SPON, London. pp. 1080-1095.

Toledo, R.D., Filho, K., Scrivener, G.L. and K. Ghavani, K. (2000). Durability of alkali- sensitive sisal and coconut fibres in cement mortar composites, The International Journal on Cement and Concrete Composites. 22(1):127-143.

Usher, O. and Oclo, O. (1979), Physical and mechanical properties of fan palm, Joint Symposium RILEM/CIB/NCCL, As a Building Materials, Bagad, pp. 102 - 105.

Veena, G., Vishal, S.G. and Rakhi.M,S. (2016). Predicting compressive strength of recycled aggregate concrete using analysis of variance. International Journal of Advanced Engineering, Management and Science, 2(6): $20-26$

www.steelconstruction.info Portal Frames Structures.

Youssef, M.A. (1976). Bamboo as a substitute for steel reinforcement in structural concrete, Part I, New Horizon in Construction Materials, Enco publishing Co. Lehigh valley Pennsyvannia USA, pp. 539554.

Yunusa, A. and Danladi, E. (2013). Properties of concrete made with ordinary Portland cement partly replaced with rice husk ash and pulverished fuel ash, Journal of Engineering and Applied Science. 5(2): $27-32$. 